\title{
Cocaine Dysregulates Dynorphin Modulation of Inhibitory Neurotransmission in the Ventral Pallidum in a Cell-Type- Specific Manner
}

\author{
Kineret Inbar, Liran A. Levi, Nimrod Bernat, Tal Odesser, ๑Dorrit Inbar, and ๑Yonatan M. Kupchik \\ Department of Medical Neurobiology, Faculty of Medicine, The Institute for Medical Research Israel-Canada, The Hebrew University of Jerusalem, \\ Israel 9112102
}

Cocaine-driven changes in the modulation of neurotransmission by neuromodulators are poorly understood. The ventral pallidum (VP) is a key structure in the reward system, in which GABA neurotransmission is regulated by opioid neuropeptides, including dynorphin. However, it is not known whether dynorphin acts differently on different cell types in the VP and whether its effects are altered by withdrawal from cocaine. Here, we trained wild-type, D1-Cre, A2A-Cre, or vGluT2-Cre:Ai9 male and female mice in a cocaine conditioned place preference protocol followed by 2 weeks of abstinence, and then recorded GABAergic synaptic input evoked either electrically or optogenetically onto identified VP neurons before and after applying dynorphin. We found that after cocaine CPP and abstinence dynorphin attenuated inhibitory input to $\mathrm{VP}_{\mathrm{GABA}}$ neurons through a postsynaptic mechanism. This effect was absent in saline mice. Furthermore, this effect was seen specifically on the inputs from nucleus accumbens medium spiny neurons expressing either the D1 or the $\mathrm{D} 2$ dopamine receptor. Unlike its effect on $\mathrm{VP}_{\mathrm{GABA}}$ neurons, dynorphin surprisingly potentiated the inhibitory input on $\mathrm{VP}_{\mathrm{VGluT2}}$ neurons, but this effect was abolished after cocaine $\mathrm{CPP}$ and abstinence. Thus, dynorphin has contrasting influences on GABA input to $\mathrm{VP}_{\mathrm{GABA}}$ and $\mathrm{VP}_{\mathrm{vGluT2}}$ neurons and these influences are affected differentially by cocaine $\mathrm{CPP}$ and abstinence. Collectively, our data suggest a role for dynorphin in withdrawal through its actions in the $\mathrm{VP}$. As $\mathrm{VP}_{\mathrm{GABA}}$ and $\mathrm{VP}_{\mathrm{vGluT2}}$ neurons have contrasting effects on drug-seeking behavior, our data may indicate a complex role for dynorphin in withdrawal from cocaine.

Key words: cocaine; dynorphin; electrophysiology; GABA; ventral pallidum; vGluT2 neurons

\section{Significance Statement}

The ventral pallidum consists mainly of GABAergic reward-promoting neurons, but it also encloses a subgroup of aversionpromoting glutamatergic neurons. Dynorphin, an opioid neuropeptide abundant in the ventral pallidum, shows differential modulation of GABA input to GABAergic and glutamatergic pallidal neurons and may therefore affect both the rewarding and aversive aspects of withdrawal. Indeed, abstinence after repeated exposure to cocaine alters dynorphin actions in a cell-typespecific manner; after abstinence dynorphin suppresses the inhibitory drive on the "rewarding" GABAergic neurons but ceases to modulate the inhibitory drive on the "aversive" glutamatergic neurons. This reflects a complex role for dynorphin in cocaine reward and abstinence.

\section{Introduction}

Failure to withdraw from chronic use of drugs is a major problem that underlies the high number of individuals suffering from drug addiction in the world. During withdrawal, many changes

Received Feb. 1, 2019; revised Dec. 5, 2019; accepted Dec. 5, 2019.

Author contributions: K.I., D.I., and Y.M.K. designed research; K.I., L.A.L., N.B., and T.O. performed research; K.I., L.A.L., N.B., and Y.M.K. analyzed data; Y.M.K. wrote the paper.

This work was supported by the Israeli Science Foundation (Grant 1381/15 to Y.M.K.) and by the Faye \& Max Warshafsky Medical Research Scholarship awarded to K.I.

The authors declare no competing financial interests.

Correspondence should be addressed to Yonatan M. Kupchik at yonatank@ekmd.huji.ac.il.

https://doi.org/10.1523/JNEUROSCI.1262-19.2019

Copyright $\odot 2020$ the authors occur in the reward system that engrave the irresistible urge to use the drugs (Kalivas and Volkow, 2005; Lüscher, 2016; Scofield et al., 2016; Dong et al., 2017). These changes are thought to underlie the dysphoric and aversive symptoms people with drug addiction experience during withdrawal and encompass synaptic and genetic changes in many brain regions, and particularly in the nucleus accumbens (NAc; Conrad et al., 2008; Gipson et al., 2013; Barrientos et al., 2018).

The main target of NAc projection neurons is the ventral pallidum (VP; Zahm and Heimer, 1990; Heimer et al., 1991). The VP is part of the basal forebrain that is deeply involved in encoding of the hedonic features of reward (Smith and Berridge, 2005; Tindell et al., 2006; Tachibana and Hikosaka, 2012; Richard et al., 2018), 
and is important in mediating cueinduced relapse to cocaine and alcohol (Stefanik et al., 2013; Prasad and McNally, 2016; Heinsbroek et al., 2017). Neurotransmission in the $\mathrm{VP}$ is mostly GABAergic (Kupchik and Kalivas, 2013) and arises mainly from two populations of medium spiny neurons (MSNs) in the NAc; those expressing the D1 (D1-MSNs) or the D2 (D2-MSNs) dopamine receptors (Zahm and Heimer, 1990; Bock et al., 2013; Kupchik et al., 2015; Creed et al., 2016; Matsui and Alvarez, 2018). Interestingly, these two inputs coexpress two different opioid neuropeptides; dynorphin (in D1-MSNs) and enkephalin (in D2MSNs). In a previous study we have described a potential role for enkephalin in withdrawal from cocaine (Kupchik et al., 2014), showing that enkephalin modulates GABA neurotransmission in the VP through a presynaptic mechanism and that this modulation is weakened after withdrawal from cocaine. However, the role of VP dynorphin in regulating neurotransmission in the VP and in withdrawal from cocaine is still not known.

Dynorphin is a selective agonist of the $\kappa$-opioid receptor (KOR; Chavkin et al., 1982) and had been repeatedly linked to dysphoria and anhedonia, particularly in the context of withdrawal from drugs (Shippenberg et al., 2007; Chavkin and Koob, 2016). Both dynorphin and the KOR are abundant in the VP. Interestingly, KORs seem to be primarily postsynaptic in the VP and in close proximity to the presynaptic dynorphin (Arvidsson et al., 1995; Allen Institute for Brain Science, 2004; Lein et al., 2007). This is in contrast to the $\mu$-opioid receptors, the target of enkephalin, who are mainly presynaptic in the VP (Olive et al., 1997). Postmortem investigation revealed that dynorphin levels in the VP of individuals who suffered from addiction to cocaine are increased by $>300 \%$ (Frankel et al., 2008). Also, dynorphin mRNA levels in NAc D1-MSNs (which project to the VP) are increased after cocaine self-administration (Hurd et al., 1992). This increase in dynorphin signaling may be related to the dysphoric symptoms of withdrawal rather than the hedonic effect of the drug because KOR phosphorylation levels in the VP increase also after injection of the stressful agent corticotropin-releasing factor (Land et al., 2008).

In this study, we use whole-cell patch-clamp recordings combined with optogenetics and an animal model of withdrawal from cocaine to characterize the dynorphinergic modulation of GABA neurotransmission in the VP in health and determine whether and how this modulation is altered after repeated cocaine exposure followed by abstinence. Moreover, we examine whether dynorphin affects differently D1-MSN and D2-MSN inputs to the VP and whether glutamate-expressing cells in the VP ( $\mathrm{VP}_{\mathrm{vGluT2} 2}$; Geisler et al., 2007), who were recently suggested to encode aversive behavior (Faget et al., 2018; Tooley et al., 2018), are affected differently by dynorphin.

\section{Materials and Methods}

Animals and housing. Experimentally naive C57BL/6J mice of both sexes (overall 41 males, 35 females) aged 8-10 weeks were group-housed (4/ cage) throughout the experiments (males separately from females). A
$12 \mathrm{~h}$ light/dark cycle was maintained at all times, with lights off at 8:00 A.M. Mice were either wild-type (Envigo) or transgenic: D1-Cre (MMRRC, stock \#029178-UCD, breeding hemizygous $\times$ wild-type), A2A-Cre (MMRRC stock \#036158-UCD, breeding hemizygous $\times$ wildtype) and a cross between vGluT2-IRES-Cre (Jackson Laboratories, strain \#016963, breeding homozygous $\times$ homozygous) and Ai9 (Jackson Laboratories strain \#007905, breeding homozygous $\times$ homozygous) named vGluT2-Cre:Ai9.

Drugs. Cocaine hydrochloride (Tamar Marketing) was dissolved in sterile saline and filtered before use. Dynorphin A and NorBNI (Abcam) were first dissolved in water and then added to aCSF solution containing also CNQX (Alomone Labs).

Behavioral procedures. Behavioral procedures started after 2 weeks of acclimation to the reverse light cycle, when the mice were $\sim 10$ weeks old. For cocaine CPP, all mice were trained in the unbiased cocaine conditioned place preference $(\mathrm{CPP})$ paradigm; a $30 \mathrm{~cm} \times 30 \mathrm{~cm}$ arena was divided in two, each side with different wall patterns and floor texture (Fig. 1). On the first day, all mice were allowed to explore the arena freely. Then, experimental mice received one daily injection of either cocaine (in the paired side, $15 \mathrm{mg} / \mathrm{kg}$, i.p.; Mu et al., 2011; Turner et al., 2018) or saline (in the unpaired side). Each side of the box served as a cocainepaired side for one-half of the mice. Cocaine/saline injections alternated daily until each mouse received four injections of each. Then, mice were left in their cages for $14 \mathrm{~d}$ before being tested for preference of the cocaine-paired side or before electrophysiological recordings began. During the test $(15 \mathrm{~min})$, mice were placed in the CPP box with free access to both paired and unpaired sides. Mouse movement was tracked (EthoVision XT 11.5, Noldus) and quantified off-line. CPP score was calculated using the following equation: CPP score = time in paired zone - time in unpaired zone

time in paired zone + time in unpaired zone . As shown (Fig. 1 B, C), cocaine mice demonstrated a strong preference for the drug-paired side [Saline mice $(n=8)$, CPP score: $0.09 \pm 0.29$; Cocaine mice $(n=10)$, CPP score: $0.40 \pm 0.25$; unpaired $t$ test comparing cocaine to saline mice: $t_{(16)}$ $=2.38, p=0.03]$. For food CPP we used the same protocols as for the cocaine CPP, but mice received high-fat, high-sugar food pellets (D12451, 45\% kcal fat, $4.73 \mathrm{kcal} \mathrm{g}^{-1}$; Research Diets) as the reward and allowed to stay in the box $30 \mathrm{~min}$ in each conditioning session. For the cocaine intraperitoneal protocol, mice received daily injections of cocaine $(15 \mathrm{mg} / \mathrm{kg}$, i.p.) for 5 consecutive days and returned to their home 
A

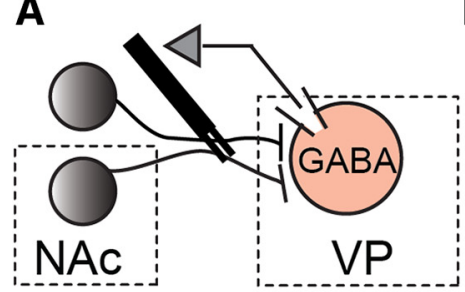

C

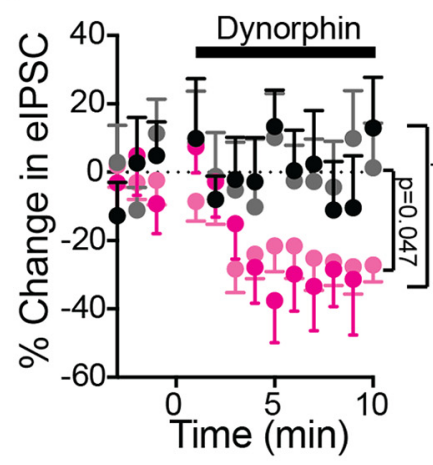

E

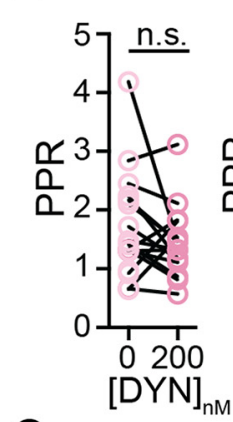

B
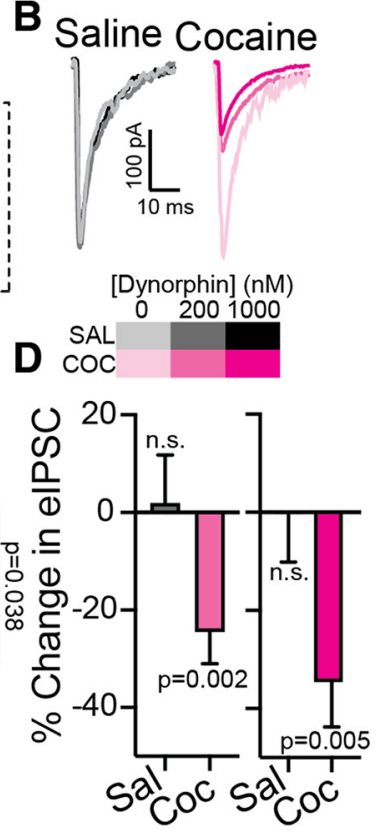

G

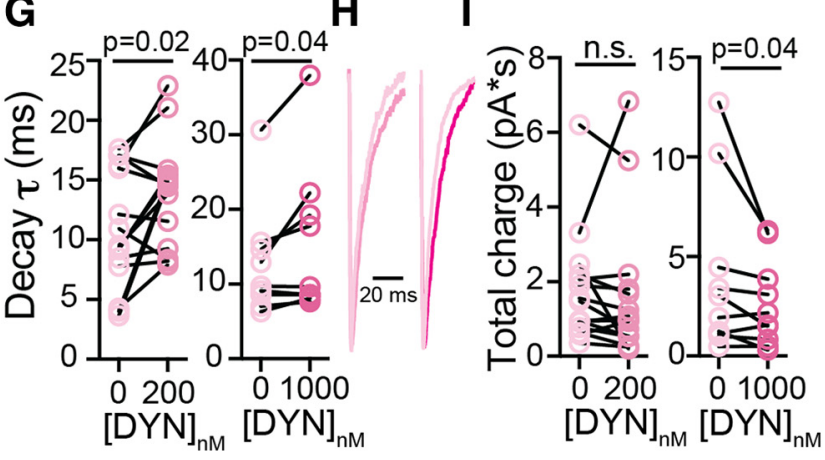

Figure 2. Dynorphin suppresses $G A B A$ neurotransmission to $\mathrm{VP}_{\mathrm{GABA}}$ neurons after abstinence from cocaine. Data presented as mean \pm SEM. $A$, Schematic drawing of the recording setup. Stimulating electrode was placed rostral to the VP, along the presumed path of NAc and possibly other GABAergic projections, to evoke GABA neurotransmission in the VP. Synaptic events were recorded from neurons that were identified as GABA neurons based on their physiology (see Materials and Methods). $\boldsymbol{B}$, Representative elPSC traces from saline (grayscale) and cocaine (magenta scale) mice. $\boldsymbol{C}, \boldsymbol{D}$, Time course $(\boldsymbol{C})$ and average $(\boldsymbol{D})$ of the effect of 200 and $1000 \mathrm{~nm}$ dynorphin on elPSCs in saline (gray) and cocaine (magenta) mice. Dynorphin suppressed elPSCs in both concentrations in cocaine, but not saline mice (time courses, two-way, repeated-measures ANOVA, group main effects: $F_{(1,25)}=4.35$ for 200 nm dynorphin and $F_{(1,25)}$ $=5.08$ for $1000 \mathrm{~nm}$ dynorphin; averages: one-sample $t$ test, comparing to $0 \%$ change). $\boldsymbol{E}$, Dynorphin did not affect the PPR of the elPSCs (paired $t$ test, $t_{(15)}=1.44, p=0.17$ for $200 \mathrm{~nm}$ dynorphin, $t_{(9)}=1.54, p=0.16$ for $1000 \mathrm{~nm}$ dynorphin) after cocaine (PP and abstinence. $F$, Dynorphin did not affect the CV of the elPSCs (paired $t$ test, $t_{(15)}=0.65, p=0.53$ for $200 \mathrm{~nm}$ dynorphin, $t_{(9)}=0.33, p=0.75$ for $1000 \mathrm{~nm}$ dynorphin) after cocaine (PP and abstinence. $\boldsymbol{G}$, Dynorphin significantly increased the decay time-constant of the elPSCs (paired $t$ test, $t_{(15)}=$ $2.57, p=0.02$ for $200 \mathrm{~nm}$ dynorphin, $t_{(9)}=2.39, p=0.04$ for $1000 \mathrm{~nm}$ dynorphin) after cocaine

cage after every injection. All procedures were approved by the Research Animal Care Committee of the Hebrew University.

Viral injections. Mice were anesthetized with isoflurane and fixed in a stereotaxic frame (Kopf, Model 940). Bilateral holes were drilled in the skull and $300 \mathrm{nl}$ of virus were microinjected through a $30 \mathrm{G} \mathrm{NanoFil}$ syringe (World Precision Instruments; $100 \mathrm{nl} / \mathrm{min}$, needle retracted slowly 5 min after injection terminated). The viral construct (AAV2EF1a-DIO-hChR2(H134R)-EYFP, generated by Karl Deisseroth and sold by University of North Carolina Viral Core) was injected into the nucleus accumbens (injection coordinates in $\mathrm{mm}$ relative to bregma, anterior/posterior: +1.8 ; medial/lateral: \pm 1 ; dorsal/ventral: -4.6$)$ of D1-Cre or A2A-Cre mice.

Slice preparation. As described previously (Kupchik et al., 2015), mice were anesthetized $(150 \mathrm{mg} / \mathrm{kg}$ ketamine $\mathrm{HCl})$, decapitated, and sagittal or coronal slices $(200 \mu \mathrm{m})$ of the VP were prepared (VT1200S Leica vibratome). Slices were transferred to a vial containing aCSF (in mM: 126 $\mathrm{NaCl}, 1.4 \mathrm{NaH}_{2} \mathrm{PO}_{4}, 25 \mathrm{NaHCO}_{3}, 11$ glucose, $1.2 \mathrm{MgCl}_{2}, 2.4 \mathrm{CaCl}_{2}, 2.5$ $\mathrm{KCl}, 2.0 \mathrm{NaPyruvate}, 0.4$ ascorbic acid, bubbled with $95 \% \mathrm{O}_{2}$ and $5 \%$ $\mathrm{CO}_{2}$ ) and a mixture of $5 \mathrm{~mm}$ kynurenic acid and $100 \mu \mathrm{M}$ MK-801. Slices were stored at room temperature $\left(22-24^{\circ} \mathrm{C}\right)$ until recording.

Whole-cell recordings. All recordings were collected at $32^{\circ} \mathrm{C}(\mathrm{TC}-344 \mathrm{~B}$, Warner Instruments). Ventral pallidal neurons were visualized with an Olympus BX51WI microscope. Excitatory synaptic transmission was blocked with CNQX (10 $\mu \mathrm{M})$. MultiClamp 700B (Molecular Devices) was used to record IPSCs in whole-cell configuration. Glass microelectrodes (1.3-2 M $\Omega$ ) were filled with internal solution (in mM: $68 \mathrm{KCl}, 65$ D-gluconic acid potassium salt, 7.5 HEPES potassium, 1 EGTA, 1.25 $\mathrm{MgCl}_{2}, 10 \mathrm{NaCl}, 2.0 \mathrm{MgATP}$, and 0.4 NaGTP, pH 7.2-7.3, $\left.275 \mathrm{mOsm}\right)$. In most experiments (see Figs. 2-6) we targeted "classic" GABAergic cells (Kupchik and Kalivas, 2013). Cholinergic and accumbens-like VP neurons were avoided based on their soma size and physiology (Bengtson and Osborne, 2000; Kupchik and Kalivas, 2013). VP $\mathrm{vGluT2}_{\mathrm{v}}$ neurons were, if at all, patched in negligible numbers (except for Fig. 7, where they were specifically targeted) based on their $5-10 \%$ prevalence in the mediocaudal VP, where we performed our experiments [observed by others (Faget et al., 2018) and us (data not shown)]. Recordings started no earlier than $10 \mathrm{~min}$ after the cell membrane was ruptured. Data were acquired at $10 \mathrm{kHz}$ and filtered at $2 \mathrm{kHz}$ using AxoGraph $\mathrm{X}$ software (AxoGraph Scientific). To evoke IPSCs electrically, a bipolar stimulating electrode was placed $\sim 200-300 \mu \mathrm{m}$ anterior of the cell to maximize chances of stimulating NAc afferents (although other GABAergic afferents were most likely activated as well). For the optogenetic experiments (see Fig. 6), we used a $470 \mathrm{~nm}$ LED light source (Mightex Systems) directed to the slice through the objective. The stimulation $1 \mathrm{~ms}$ pulse intensity was set to evoke $50 \%$ of maximal IPSC. Recordings were collected every $20 \mathrm{~s}$. Series resistance (Rs), measured with a $-2 \mathrm{mV}$ depolarizing step (10 ms) given with each stimulus, and holding current were monitored online. Recordings with unstable $R$ s, or when $R$ s exceeded 20 $\mathrm{M} \Omega$ were aborted.

Data analysis. Statistics were performed using GraphPad Prism 8.0. Data on evoked neurotransmission (see Figs. 2, 4-7) are given as percentage change and not in raw numbers because of the high variability of the evoked IPSC amplitudes within groups. In graphs showing the timedependent effect of dynorphin on GABA currents (see Figs. 2C, $3 A, D$, $4 C, 5 A, 6 C, D, 7 C, F, I)$ the two-way repeated-measures ANOVA was performed on minutes 1-10 and accompanying average bar graphs were calculated from the same time points. Parametric statistics (Student's $t$ test, one-sample $t$ test, one-way or two-way repeated-measures ANOVA) was used unless otherwise stated. Nonparametric statistics (Kolmogoro$\mathrm{v}-$ Smirnov tests) were used in Figures 3, 5, and 7 to compare cumulative plots. The cumulative probability curve depicted in Figures 3, 5, and 7 is

CPP and abstinence. $\boldsymbol{H}$, Representative traces showing the effect of 200 and $1000 \mathrm{~nm}$ dynorphin on the decay of the elPSC.I, Dynorphin (only at $1000 \mathrm{~nm}$ ) significantly decreased the total charge of the elPSCs (paired one-tailed $t$ test, $t_{(15)}=0.39, p=0.35$ for 200 nm dynorphin, $t_{(9)}=1.89$, $p=0.04$ for $1000 \mathrm{~nm}$ dynorphin). Number of cells was between 9 and 22 from 4 to 11 mice for all conditions. n.s., not significant. 
A
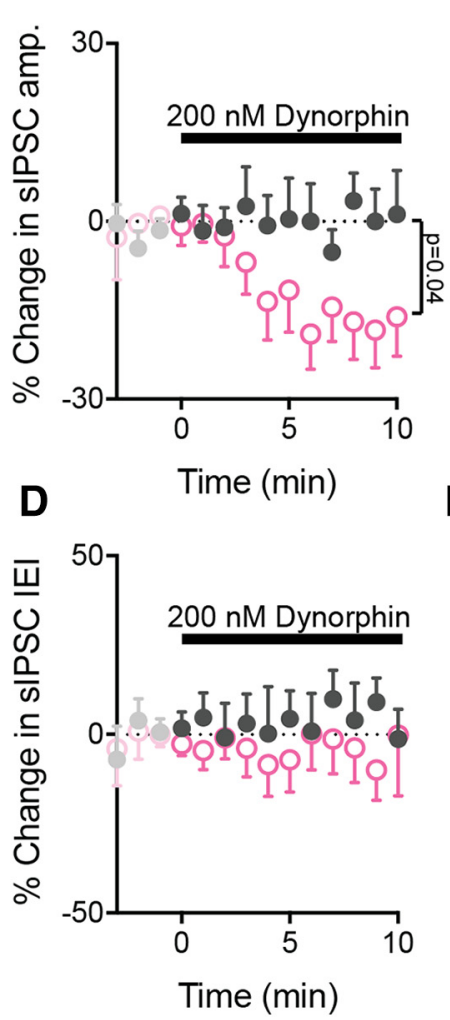

B

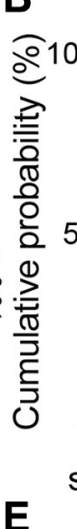

\section{E}

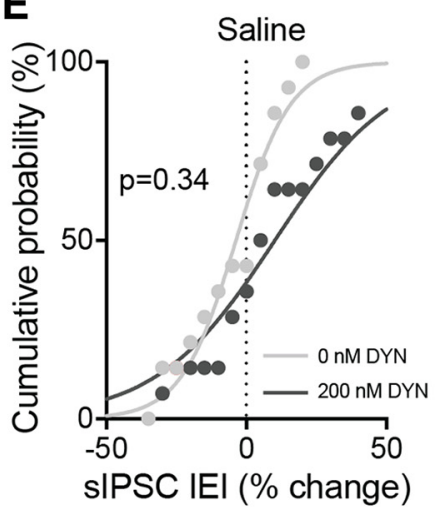

C

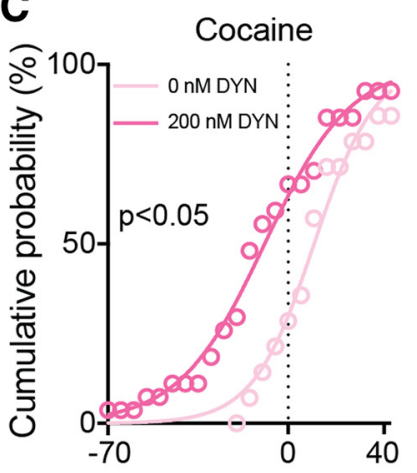

G

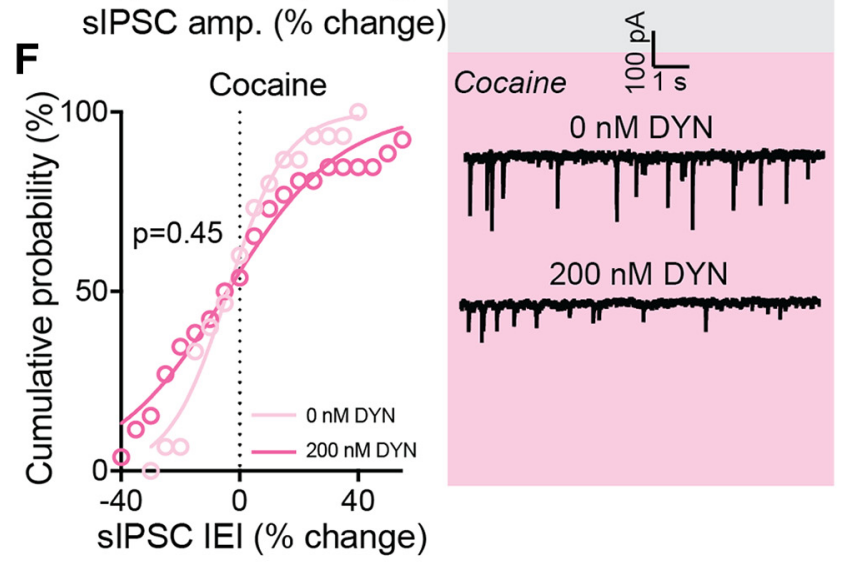

Figure 3. Dynorphin reduces the amplitude of spontaneous $G A B A$ currents in $\mathrm{VP}_{\mathrm{GABA}}$ neurons of cocaine-withdrawn mice. $A-C$, Dynorphin (200 nm) decreased the amplitude of sIPSCs in VP ${ }_{G A B A}$ neurons after cocaine CPP and abstinence (magenta) but not in saline mice ( $g r a y)$. This is seen both in the time course of the effect of dynorphin ( $A$; main group effect, two-way repeated-measures ANOVA: $F_{(1,30)}=4.26, p=0.04$ ) and in the cumulative probability plots (Kolmogorov-Smirnov test). Lines are fitted sigmoidal curves running from 0 to $100 . \boldsymbol{D}-\boldsymbol{F}$, Dynorphin (200 nm) did not affect the frequency of sIPSCS, measured as IEl. G, Representative traces, depicting the increased suppressive effect of dynorphin on sIPSC amplitude after withdrawal from cocaine. Number of cells was between 8 and 28 from 3 to 11 mice for all conditions.

a fitted sigmoidal curve running from 0 to 100, computed by GraphPad Prism 8.0. Data in Results and figure legends are presented as mean \pm $\mathrm{SD}$. Error bars in graphs represent SEM.

\section{Results}

Cocaine CPP and abstinence causes strong dynorphininduced suppression of GABA neurotransmission onto VP $_{\text {GABA }}$ neurons

The current study aims to reveal a possible role for dynorphin in mediating long-lasting changes occurring in the VP after abstinence from cocaine. To achieve that, we first examined whether dynorphin regulates evoked GABA neurotransmission in the VP. We stimulated electrically the GABAergic input to the VP and recorded from unlabeled VP neurons (Fig. 2A). As the proportion of glutamatergic neurons in the VP is low [only 29 cells per $10^{7} \mu \mathrm{m}^{3}$ tissue (Hur and Zaborszky, 2005); 7\% of neurons in our hand (data not shown)] and cholinergic neurons are scarce in the VP and can be identified by their morphological and physiological parameters (Bengtson and Osborne, 2000), we assume that $>95 \%$ of patched unlabeled neurons are in fact classical GABAergic ventral pallidal neurons $\left(\mathrm{VP}_{\mathrm{GABA}}\right.$; see Materials and Methods). In cocaine-naive mice (injected with saline), dynorphin did not affect the amplitude of the electrically-evoked IPSC (eIPSC) both at 200 and $1000 \mathrm{~nm}$ (Fig. 2B-D; average percentage change from baseline was $1.95 \pm 31.09$ and $-0.29 \pm 27.92$ for 200 and $1000 \mathrm{~nm}$ dynorphin, respectively; one-sample $t$ test comparing to $0 \%$ change from baseline: $t_{(9)}=0.20, p=0.85$ and $t_{(7)}=0.03, p=$ 0.98 for 200 and $1000 \mathrm{~nm}$ dynorphin). In contrast, in mice that underwent cocaine CPP and abstinence dynorphin attenuated
eIPSCs in the VP (Fig. 2B-D); eIPSCs were decreased by $24.5 \pm$ $6.5 \%$ and $34.6 \pm 9.2 \%$ with 200 and $1000 \mathrm{~nm}$ dynorphin, respectively (two-way, repeated-measures ANOVA, main group effects comparing cocaine and saline groups within each dynorphin concentration, $F_{(1,25)}=4.35, p=0.047$ for $200 \mathrm{nM}$ dynorphin and $F_{(1,25)}=5.08, p=0.038$ for $1000 \mathrm{nM}$ dynorphin; one-sample $t$ tests comparing to baseline: $t_{(16)}=3.74, p=0.002$ and $t_{(8)}=$ $3.77, p=0.005$ for 200 and $1000 \mathrm{~nm}$ dynorphin, respectively).

We have previously shown that enkephalin, an opioid neuropeptide that binds $\delta$ - and $\mu$-opioid receptors, inhibits eIPSCs in the VP via a presynaptic mechanism (Kupchik et al., 2014). To examine whether this is the case also for dynorphin we used a dual approach: (1) examination of the characteristics of the evoked IPSCs, including the paired-pulse ratio (PPR) and the coefficient of variation $(\mathrm{CV})$, both indicators of presynaptic changes, and the decay time constant, which reflects postsynaptic mechanisms; and (2) examination of the frequency and amplitude of the spontaneous IPSCs (sIPSCs). In contrast to enkephalin, our convergent approach suggests that the effect of dynorphin in the VP after cocaine CPP and abstinence is more likely to be mediated by a postsynaptic mechanism. First, dynorphin application did not change the PPR (Fig. $2 E$; paired $t$ test: $t_{(15)}=1.44, p=0.17$ and $t_{(9)}=1.54, p=0.16$ for 200 and $1000 \mathrm{~nm}$ dynorphin, respectively). Lack of change in the PPR is often interpreted as lack of change in the probability of synaptic release, but this interpretation should be taken with caution, as G-protein-coupled receptors, including the KOR (the target of dynorphin), were shown to have a presynaptic site of action without changing the PPR (Li et 
al., 2012). Second, application of dynorphin did not affect the CV of eIPSCs (Fig. $2 F$; paired $t$ test: $t_{(15)}=0.65, p=0.53$ and $t_{(9)}=$ $0.33, p=0.75$ for 200 and $1000 \mathrm{~nm}$ dynorphin, respectively), again advocating against a presynaptic mechanism of action. In contrast, we found that dynorphin application on slices of cocaine-withdrawn mice increased the decay time constant of the eIPSCs (Fig. $2 G, H$; paired $t$ test: $t_{(15)}=2.57, p=0.02$ and $t_{(9)}=$ $2.39, p=0.04$ for 200 and $1000 \mathrm{~nm}$ dynorphin, respectively), suggesting a postsynaptic site of action for dynorphin. Note that longer decay time constants allow for more charge to flow through the channels. Thus, the dynorphin-induced prolongation of the eIPSC decay promotes, while the dynorphin-induced suppression of the eIPSC peak attenuates, charge flow. When examining whether dynorphin inhibited the total charge (calculated as the area under the eIPSC curve) despite the increase in the decay time constant, we found that only $1000 \mathrm{~nm}$ dynorphin was sufficient to decrease significantly the total charge in mice after cocaine CPP and abstinence (Fig. 2I; paired $t$ test: $t_{(15)}=0.39, p=$ 0.35 and $t_{(9)}=1.89, p=0.04$ for 200 and $1000 \mathrm{~nm}$ dynorphin, respectively).

To supplement the observations on the eIPSCs, we also examined the effect of dynorphin on the amplitude and frequency of spontaneous IPSCs. To achieve this, we calculated the dynorphininduced change in each recorded cell and then compared the averages (Fig. $3 A, D, G$ ) and cumulative probabilities of these changes on sIPSC amplitude (Fig. $3 B, C$ ) and inter-event interval (IEI; Fig. $3 E, F$ ) at a concentration of $200 \mathrm{nM}$. We found that 200 nM dynorphin caused a decrease in the average sIPSC amplitude (two-way, repeated-measures ANOVA, main group effect comparing cocaine and saline groups: $\left.F_{(1,30)}=4.26, p=0.047\right)$ and a leftward shift in the sIPSC amplitude plot toward negative values (Kolmogorov-Smirnov test, $D=0.45, p=0.045$ ), but only after cocaine $\mathrm{CPP}$ and abstinence. In contrast, dynorphin had no effect on the IEI (average sIPSC IEI: two-way, repeated-measures ANOVA, no main group effect comparing cocaine and saline groups: $F_{(1,30)}=0.32, p=0.57$; IEI cumulative plots: Kolmogorov-Smirnov test, $D=0.28, p=0.45$ ). Because changes in sIPSC amplitude reflect postsynaptic mechanisms, these results, together with the analysis of eIPSCs (Fig. 2), support the hypothesis that after cocaine CPP and abstinence dynorphin inhibits the amplitude of the GABAergic input to $\mathrm{VP}_{\mathrm{GABA}}$ neurons through a postsynaptic mechanism.

\section{The effect of dynorphin on eIPSCs is strongest in a cocaine CPP and abstinence model}

We next wanted to examine whether the effects of dynorphin on the eIPSCs seen in mice after cocaine CPP and withdrawal are more likely to be generated by the mere exposure to cocaine or by the CPP training. We thus used two more groups of mice. The first group (Fig. 4A) received five intraperitoneal injections of cocaine, whereas another group (Fig. $4 B$ ) was trained on CPP using high-fat-high-sugar food as the reward. In both groups, recordings were performed $14 \mathrm{~d}$ after the last exposure to reward. We found that dynorphin application (1000 nM) on slices from mice that underwent food CPP did not affect eIPSC amplitude or PPR (Fig. 4C-E; average $0.05 \pm 18.2 \%$ of baseline; one-sample $t$ test compared with baseline: $t_{(13)}=0.01, p=0.99$ and $t_{(13)}=$ $0.08, p=0.94$ for eIPSC amplitude and PPR, respectively). In contrast, in the mice that received the five intraperitoneal cocaine injections dynorphin showed some nonsignificant suppression of the eIPSC (average $-7.56 \pm 13.2 \%$ of baseline; one-sample $t$ test compared with baseline: $t_{(13)}=0.1 .26, p=0.23$ ), although this was much less pronounced than the effect of dynorphin in
A

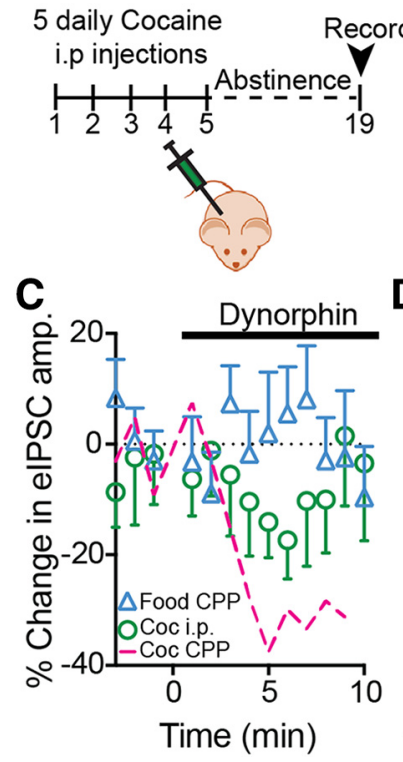

B
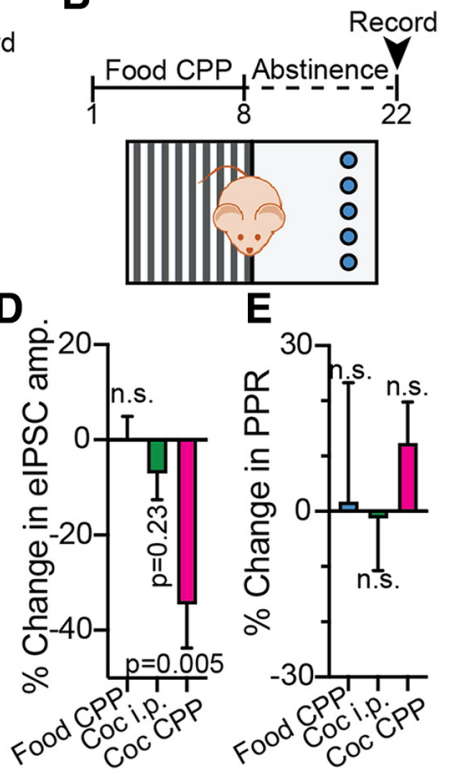

Fod

Figure 4. The dynorphinergic changes in the VP are most pronounced in the cocaine CPP and abstinence paradigm. $\boldsymbol{A}$, Schematic drawing of the cocaine intraperitoneal injection protocol. Mice received five daily intraperitoneal cocaine injections, followed by $14 \mathrm{~d}$ of abstinence. $\boldsymbol{B}$, Schematic drawing of the food (PP protocol. Mice were trained for CPP just as described above for cocaine, but with high-fat, high-sugar (HFHS) food pellets as the reward (blue circles). After $8 \mathrm{~d}$ of conditioning, mice went through $14 \mathrm{~d}$ of abstinence from the HFHS food. C, D, Time course $(\boldsymbol{C})$ and average $(\boldsymbol{D})$ of the effect of $1000 \mathrm{~nm}$ dynorphin on elPSCs in the VP in the food CPP mice (blue triangles), cocaine intraperitoneal injection mice (green circles) and cocaine (PP mice (magenta line; same data as in Fig. 2, given here for comparison). It can be seen that dynorphin induced a transient small suppression of the elPSC in the cocaine intraperitoneal mice, but this effect was weak and did not reach significance (one-sample $t$ tests compared with $0 \%$ change from baseline). $\boldsymbol{E}$, Dynorphin did not affect the PPR in any of the groups (one-sample $t$ test compared with $0 \%$ change from baseline). n.s., not significant.

mice that underwent cocaine $\mathrm{CPP}$ and abstinence (average $-34.6 \pm 27.5 \%$ of baseline; one-sample $t$ test compared with baseline: $\left.t_{(8)}=3.77, p=0.005\right)$. Thus, cocaine exposure and abstinence seems to be more central to the dynorphinergic changes in the VP than the CPP training itself, although CPP training may amplify the cocaine-induced effects on dynorphin action in the VP.

\section{The effects of dynorphin in the VP are mediated by KORs}

Dynorphin is known as a selective agonist of KORs, but the VP expresses also $\delta$ - and $\mu$-opioid receptors that may also be affected by dynorphin (Zhang et al., 1998). To examine this possibility, we repeated our experiments on cocaine-abstinent mice but in the presence of the selective and long-lasting KOR blocker norbinaltorphimine (NorBNI).

Washing NorBNI alone on the slice did not have any effect on eIPSCs or sIPSCs both in saline and after cocaine CPP and abstinence (Fig. 5; eIPSCs, one-sample $t$ test compared with $0 \%$ change from baseline: $t_{(6)}=0.27, p=0.80$ and $t_{(9)}=0.10, p=$ 0.92 in saline and cocaine mice, respectively; for sIPSC amplitude, Kolmogorov-Smirnov test: $D=0.44, p=0.35$ and $D=$ $0.15, p=0.99$ in saline and cocaine mice, respectively; for sIPSC IEI, Kolmogorov-Smirnov test: $D=0.22, p=0.99$ and $D=0.31$, $p=0.57$ in saline and cocaine mice, respectively). This indicates that, in contrast to the tonic activation of $\mu$-opioid receptors by enkephalin after abstinence (Kupchik et al., 2014; Heinsbroek et al., 2017), KORs maintain a normal basal level of activity after abstinence from cocaine. Moreover, NorBNI successfully pre- 
vented dynorphin from inhibiting the eIPSCs (Fig. 5A-C; one-sample $t$ test compared with $0 \%$ change from baseline: $t_{(9)}=0.25, p=0.81$ and $t_{(4)}=0.85, p=$ 0.45 in 200 and $1000 \mathrm{~nm}$ dynorphin, respectively), changing their decay time constant (Fig. 5D-G; paired $t$ test: $t_{(7)}=$ $0.79, p=0.46)$ and affecting the amplitude or frequency of sIPSCs (Fig. $5 \mathrm{H}-\mathrm{K}$; Kolmogorov-Smirnov test: $D=0.25, p=$ 0.85 and $D=0.39, p=0.29$ for sIPSC amplitude and frequency, respectively) in mice that underwent cocaine CPP and abstinence. This, together with our data so far, indicates that the effects of dynorphin on GABA transmission onto $\mathrm{VP}_{\mathrm{GABA}}$ neurons are mediated by postsynaptic KORs.

\section{Dynorphin suppresses GABA}

transmission from D1-MSNs and D2-

MSNs in the VP in saline mice and after cocaine CPP and abstinence

The major portion of inhibitory input to the VP originates in the NAc (Zahm et al., 1985; Root et al., 2015). We and others recently showed that both populations of MSNs in the NAc, those expressing the D1 (D1-MSNs) or the D2 (D2-MSNs) dopamine receptor, provide input to the VP (Kupchik et al., 2015; Creed et al., 2016; Heinsbroek et al., 2017; Pardo-Garcia et al., 2019). These two different inputs may have different roles in encoding druginduced effects and therefore may be affected differently by dynorphin. To examine this, we activated selectively D1MSN or D2-MSN terminals in the VP with optogenetics and recorded from $\mathrm{VP}_{\mathrm{GABA}}$ neurons (Fig. 6A). Our data show that $1000 \mathrm{~nm}$ dynorphin successfully suppressed GABA transmission from both D1-MSN and D2-MSN terminals, and that this suppression was seen both in saline mice and in mice that underwent cocaine CPP and abstinence (Fig. $6 B-D$; one-sample $t$ test compared with $0 \%$ change from baseline, D1-MSN input: $8.83 \pm 13.8 \%$ suppression, $\left(\mathrm{t}_{12)}=2.3, p=\right.$ 0.04 and $-25.00 \pm 17.2 \%$ suppression, $t_{(12)}=5.24, p=0.0002$ for saline and cocaine mice, respectively; D2-MSN input: $16.9 \pm 16.6 \%$ suppression, $t_{(9)}=3.22$, $p=0.01$ and $-19.8 \pm 26.3 \%$ suppression, $t_{(9)}=2.38, p=0.04$ for saline and cocaine mice, respectively). Interestingly, cocaine CPP and abstinence strengthened the dynorphin-induced suppression of D1MSNs (Fig. 6C, inset; unpaired $t$ test: $t_{(24)}=$ $2.64, p=0.014$ ) but not of D2-MSNs (Fig.

$6 D$, inset; unpaired $t$ test: $\left.t_{(18)}=0.29, p=0.78\right)$. There was no change in the PPR or CV in both inputs (data not shown). Dynorphin also did not change on average the eIPSC decay time-constant in D1-MSN and D2-MSN inputs (Fig. 6E,F; paired $t$ test: $t_{(12)}=$

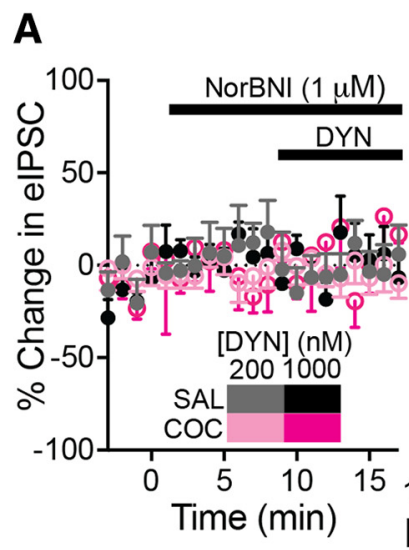

B
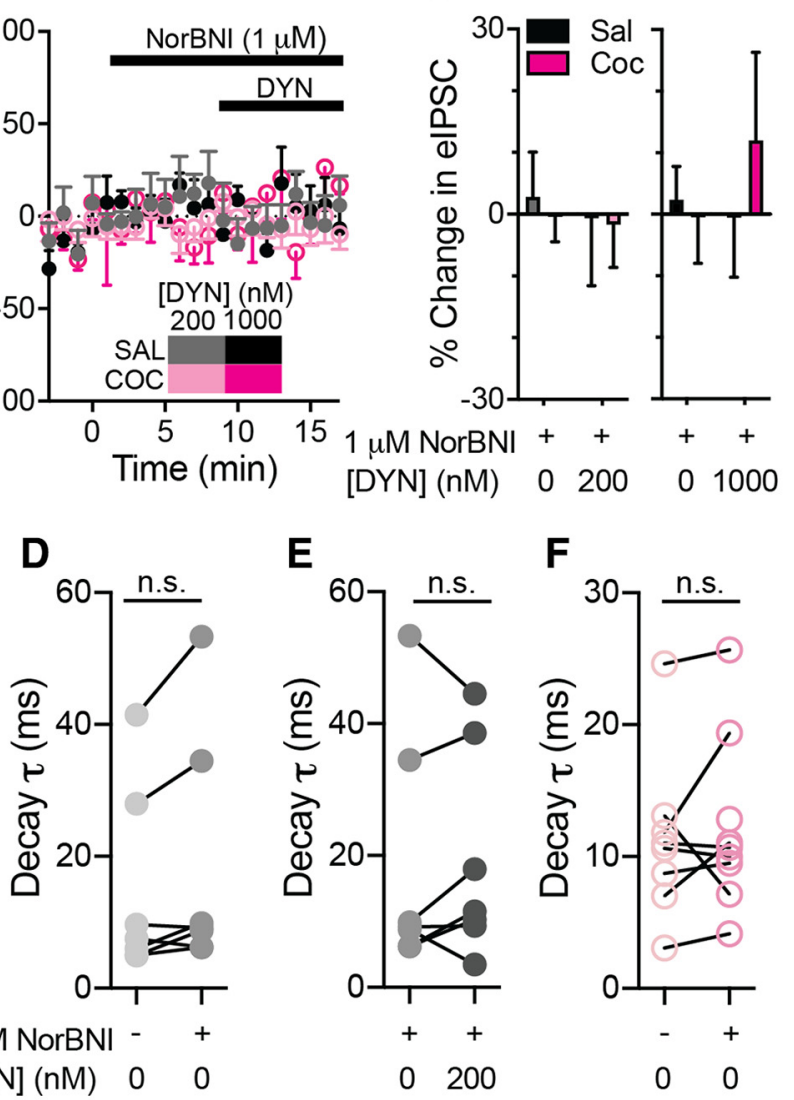

C
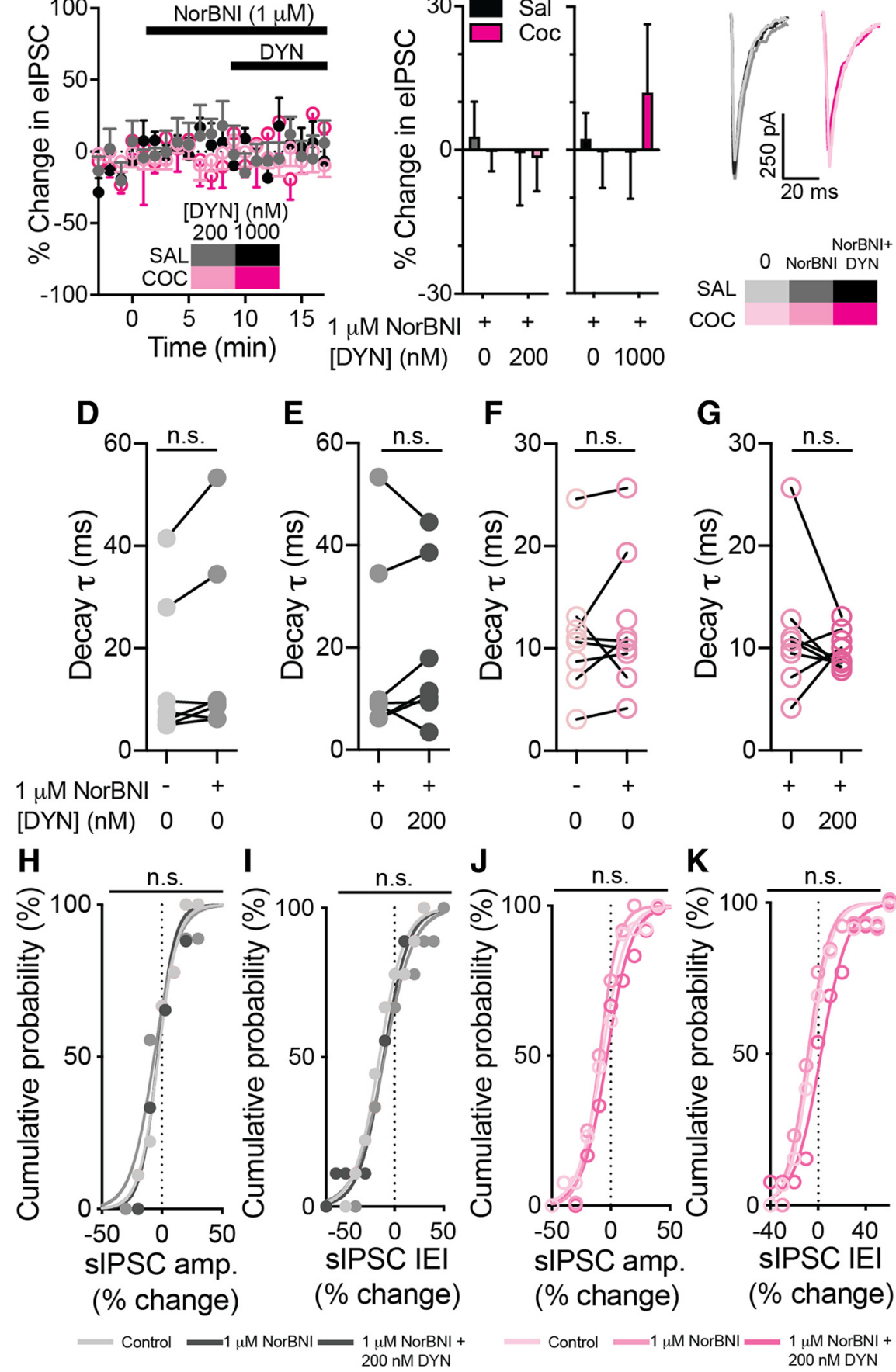

Figure 5. The effects of dynorphin are mediated by KORs. All experiments were performed by recording baseline synaptic release, then adding the KOR antagonist NorBNI (1000 nm) and finally a mixture of NorBNI and 200 or 1000 nm dynorphin. Data presented as mean \pm SEM. $A$, Time course of experiment. NorBNI alone, as well as 200 or $1000 \mathrm{~nm}$ dynorphin given together with NorBNI, did not affect the amplitude of elPSCs in either saline or cocaine mice. $\boldsymbol{B}$, Summary of experimental results presented in $\boldsymbol{A}$. None of the experimental groups was different from 0 (one-sample $t$ test). $n=4-13$ cells from 3 to 5 mice in all groups. C, Representative traces. D-G, NorBNI did not affect, and prevented the effects of dynorphin on, the elPSC decay time-constant in saline $(n=7)$ or cocaine ( $n=8)$ mice (effect examined using paired $t$ test). $\boldsymbol{H}$ - $\boldsymbol{K}$, NorBNI did not affect, and prevented the effects of dynorphin on the sIPSC amplitude and IEl in saline $(n=9)$ and cocaine-withdrawn $(n=13)$ mice. Lines are fitted sigmoidal curves running from 0 to 100 . n.S., not significant.
$1.06, p=0.31$ and $t_{(9)}=2.18, p=0.056$ for D1-MSN and D2MSN inputs, respectively); although note that 8 of 10 cells showed an increase in the decay time-constant of D2-MSN-induced eIPSCs. Overall, dynorphin inhibits both D1-MSN and D2-MSN 
A
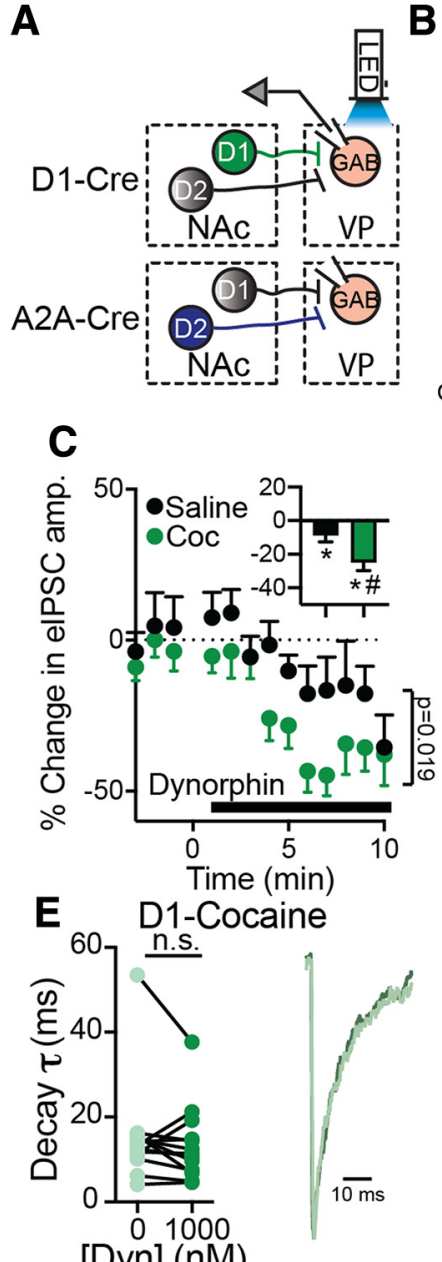

[Dyn] (nM)
B D1-MSN
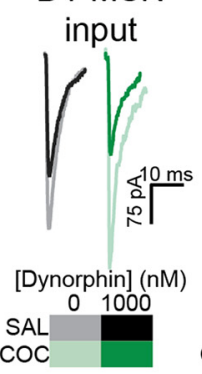

D

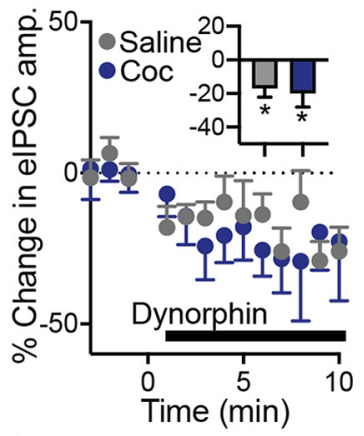

$\mathbf{F}$

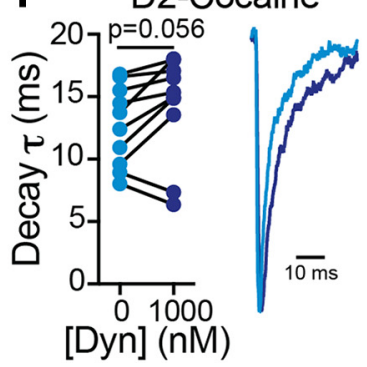

Figure 6. Dynorphin suppresses GABA neurotransmission from D1-MSN and D2-MSN terminals in the VP in saline and cocaine-withdrawn mice. $A$, Schematic representation of recording conditions. ChR2 was expressed selectively in D1-MSNs (using D1-Cre mice) or D2-MSNs (using A2A-(re mice) and the terminals were activated by $470 \mathrm{~nm}$ LED light in the VP while recording from VP ${ }_{G A B A}$ neurons (GAB). $B$, Representative traces of optogenetically-evoked IPSCs recorded from VP ${ }_{G A B A}$ neurons while activating terminals of D1-MSNs (green) or D2-MSNs (blue). C, Time course and average effect (inset) of $1000 \mathrm{~nm}$ dynorphin on D1-MSN GABA neurotransmission in the VP of saline mice (black) or mice that underwent cocaine (PP and withdrawal (green). Dynorphin suppressed GABA neurotransmission in both groups, but the suppression was stronger in the cocaine group (two-way, repeated-measures ANOVA, group main effects: $F_{(1,24)}=$ 6.29 ; averages in insets: ${ }^{*} p=0.04$ and $p=0.0002$ for saline and cocaine mice, respectively, one-sample $t$ test, comparing to $0 \%$ change; $\# p=0.01$ comparing to saline). $\boldsymbol{D}$, Dynorphin $(1000 \mathrm{~nm})$ suppressed GABA neurotransmission from D2-MSN terminals in the VP in both saline mice (gray) and after cocaine (PP and abstinence (blue; inset, averages: ${ }^{*} p=0.01$ and $p=$ 0.04 for saline and cocaine groups, respectively, one-sample $t$ test comparing to $0 \%$ change). The effect was comparable between groups. $\boldsymbol{E}$, Dynorphin (1000 nm) did not affect the decay time-constant of D1-MSN currents (paired $t$ test, $t_{(12)}=1.06, p=0.31$ ). Right, Representative traces. $\boldsymbol{F}$, Dynorphin (1000 nm) did not change the decay time-constant of D2-MSN currents (paired $t$ test, $t_{(9)}=2.18, p=0.056$ ). Data collected from 10 to 13 cells in each group from 4 to 6 mice. n.s., not significant.

inputs to the VP and cocaine CPP and abstinence seems to enhance this suppression selectively in D1-MSN input to the VP.

Dynorphin effect on $\mathrm{VP}_{\mathrm{vGluT2}}$ neurons is cocaine-dependent and different from its effect on $\mathrm{VP}_{\mathrm{GABA}}$ neurons

Dynorphin is usually linked to the expression of avoidance (Land et al., 2008; Chavkin and Koob, 2016), whereas the activity of the VP is mostly linked to reward seeking (Hubner and Koob, 1990; Smith and Berridge, 2005; Tindell et al., 2005; Tachibana and

Hikosaka, 2012; Richard et al., 2016, 2018). Recent studies have identified a subgroup of neurons in the VP that, in contrast to the GABAergic majority, express the vesicular glutamate transporter 2 (vGluT2), thus making these cells glutamatergic (Geisler et al., 2007). Behavioral examinations revealed that $\mathrm{VP}_{\mathrm{VGluT2}}$ neurons, in contrast to $\mathrm{VP}_{\mathrm{GABA}}$ neurons, encode for aversive behavior (Faget et al., 2018; Tooley et al., 2018). As dynorphin and $\mathrm{VP}_{\mathrm{vGluT2}}$ neurons both seem to encode aversion we examined whether dynorphin regulates $\mathrm{GABA}$ input to $\mathrm{VP}_{\mathrm{vGluT2}}$ neurons differently than the general $\mathrm{VP}_{\mathrm{GABA}}$ population and whether this regulation is impaired after cocaine CPP and abstinence (Fig. $7 A, B$ ). Our data show that in contrast to its effect on $\mathrm{VP}_{\mathrm{GABA}}$ neurons (Fig. 2), dynorphin potentiated the evoked inhibitory input to $\mathrm{VP}_{\mathrm{vGluT2}}$ neurons in drug-naive mice by $74.86 \pm 10.8 \%$ (Fig. $7 C-E$; twoway, repeated-measures ANOVA, main group effect comparing cocaine and saline groups: $F_{(1,113)}=49.47, p<0.0001$; unpaired $t$ test comparing dynorphin effect between saline and cocaine mice: $\left.t_{(9)}=8.93, p<0.0001\right)$. Moreover, although cocaine CPP and abstinence enhanced the effect of dynorphin in the $\mathrm{VP}_{\mathrm{GABA}}$ population (Fig. 2), it abolished the effect of dynorphin on $\mathrm{VP}_{\mathrm{v}^{-}}$ Glut2 neurons. We were not able to see any effect of dynorphin on the PPR, CV or decay time-constant of the eIPSC (data not shown), as well as effects on the amplitude or frequency of sIPSCs (Fig. $7 F-K$; Kolmogorov-Smirnov tests; saline mice: $D=0.5, p=$ 0.33 and $D=0.29, p=0.96$ for sIPSC amplitude and frequency, respectively; cocaine mice: $D=0.3, p=0.67$ and $D=0.17, p=$ 0.99 for sIPSC amplitude and frequency, respectively). Thus, we cannot determine whether the effect of dynorphin on the inhibitory input to $\mathrm{VP}_{\mathrm{vGluT2}}$ neurons is based on a presynaptic or postsynaptic mechanism.

\section{Discussion}

The VP receives accumbal input from both D1- and D2-MSNs (Kupchik et al., 2015; Creed et al., 2016; Heinsbroek et al., 2017). The role of D2-MSN terminals in the VP in motivation and drug addiction has been studied to some extent (Bock et al., 2013; Creed et al., 2016; Soares-Cunha et al., 2016; Heinsbroek et al., 2017; Gallo et al., 2018) but the role of the newly found D1-MSN terminals in the VP in addiction to cocaine is not yet known. Here we investigated the long-term changes induced by cocaine CPP and abstinence in the action of dynorphin, an opioid neuropeptide released from NAc D1-MSN axons (among other potential sources like the lateral hypothalamus, substantia nigra, and more; Khachaturian et al., 1982; Chou et al., 2001; Ho and Berridge, 2013; Thomas et al., 2018) in the VP. We found that dynorphin had cell-type-specific effects in the VP, with contrasting effects on $\mathrm{VP}_{\mathrm{GABA}}$ and $\mathrm{VP}_{\mathrm{vGluT2}}$ neurons in saline and cocaine mice (Fig. 7). In saline mice, dynorphin did not affect evoked GABA input to $\mathrm{VP}_{\mathrm{GABA}}$ neurons but potentiated eIPSC amplitude in $\mathrm{VP}_{\mathrm{vGluT2}}$ neurons. In contrast, after cocaine CPP and abstinence dynorphin suppressed eIPSCs in $\mathrm{VP}_{\mathrm{GABA}}$ neurons, whereas it lost its potentiating effect on the inhibitory input to $\mathrm{VP}_{\mathrm{vGluT2}}$ neurons. Dynorphin-induced suppression of eIPSCs in $\mathrm{VP}_{\mathrm{GABA}}$ neurons was observed also when activating selectively the input from D1-MSNs and D2-MSNs with optogenetic tools, regardless of cocaine experience. Last, an examination of eIPSC parameters (PPR, CV, and decay time-constant) and the amplitude and frequency of sIPSCs indicated that the effects of dynorphin are most likely mediated by postsynaptic KORs. Overall, our data show that dynorphin regulates GABA input to the VP from different inputs and on different VP cell types, and that abstinence from cocaine causes drastic changes in the actions of dynorphin in the VP. These changes present a mechanism by which dynorphin in the VP may contribute to addictive behavior. 
A

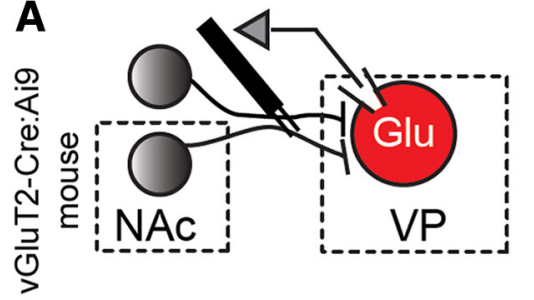

B
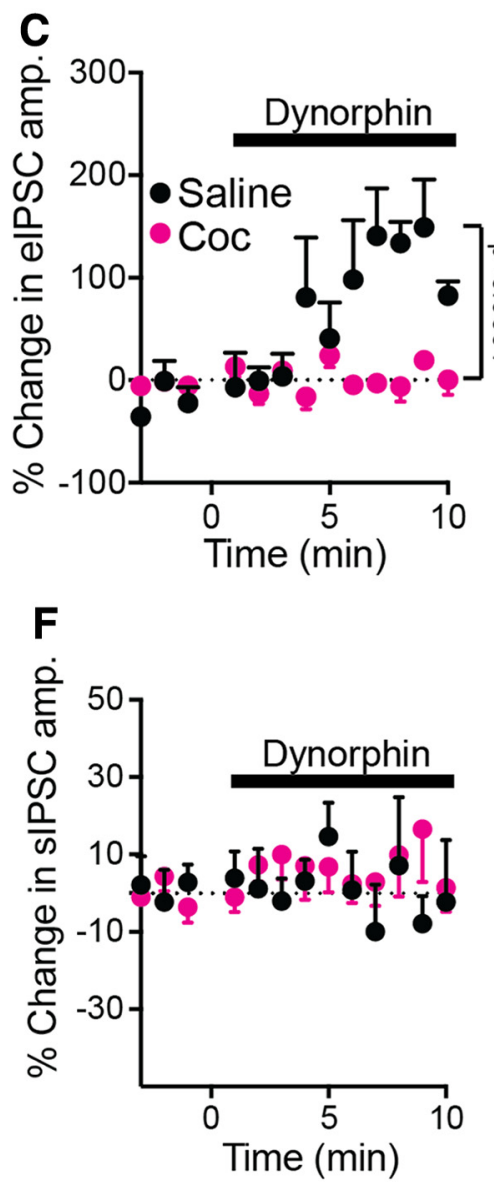

I

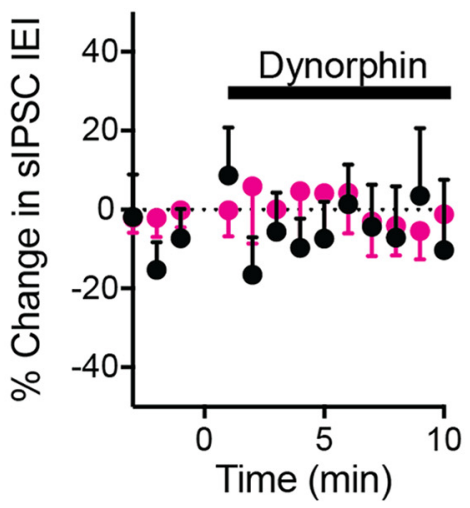

G

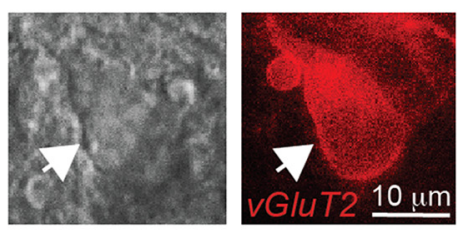

D $\quad E$

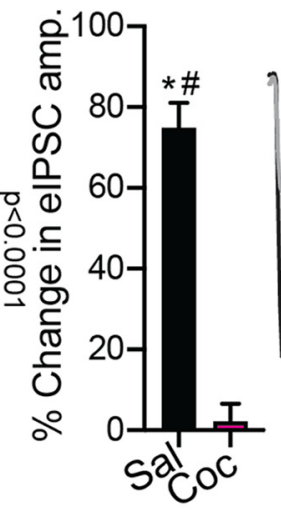

Saline Cocaine

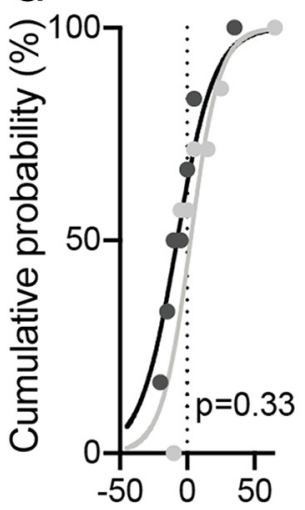

sIPSC amp.
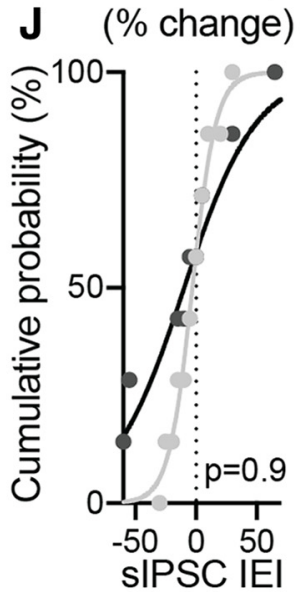

(\% change)
H

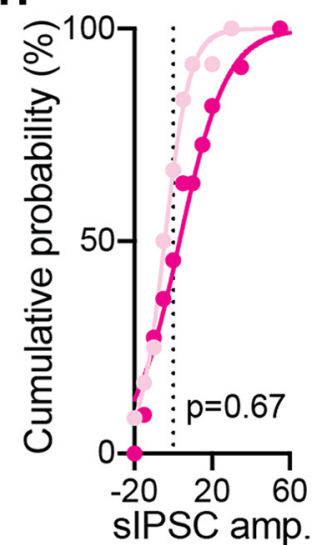

K (\% change)

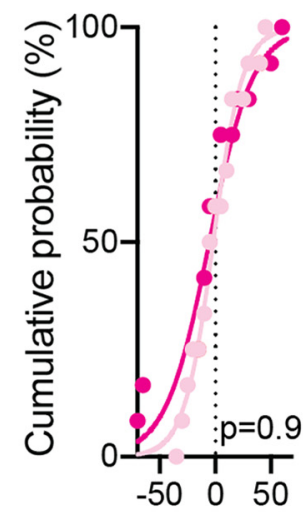

SIPSC IEI

( $\%$ change)

Figure 7. Cocaine CPP and abstinence abolishes dynorphin-induced potentiation of inhibitory input to VP $\mathrm{vGluT2}_{2}$ neurons $\boldsymbol{A}$, Schematic representation of recording conditions. $\mathrm{VP}_{\mathrm{vGluT2}}$ neurons (Glu) were identified in vGluT2-Cre:Ai9 mice (express tdTomato in vGluT2-expressing neurons) and patched while evoking synaptic transmission with electrical stimulations. $\boldsymbol{B}$, Micrographs showing a $\mathrm{VP}_{\mathrm{vGluT2}}$ neuron that was recorded from in bright field (left) and fluorescence (right). $\boldsymbol{C}, \boldsymbol{D}$, Time course $(\boldsymbol{C})$ and average $(\boldsymbol{D})$ effect of dynorphin (1000 nm) on elPSCs in VP $\mathrm{vGluT2}_{2}$ neurons. Dynorphin potentiated evoked GABA input to VP

Contrasting effects for dynorphin and enkephalin in the VP

The D1- and D2-MSN terminals in the VP release, in addition to GABA, also the opioid neuropeptides dynorphin and enkephalin, respectively (Zahm et al., 1985; Lu et al., 1998; Gerfen and Surmeier, 2011). Comparing our current data on dynorphin with our previous study on enkephalin in the VP (Kupchik et al., 2014), we find that these two neuropeptides act in different and complementary patterns. First, we show here that dynorphin modulates GABA neurotransmission in the VP through a postsynaptic mechanism while enkephalin acts presynaptically. Interestingly, this is in line with the pattern of expression of their respective receptors; dynorphin binds the KOR, which is expressed more robustly in the VP than in striatal neurons, whereas enkephalin acts on $\mu$ - and $\delta$-opioid receptors, which are heavily expressed in striatal neurons (Mansour et al., 1994). Second, whereas withdrawal from cocaine blunts the effect of enkephalin on GABA transmission in the VP (Kupchik et al., 2014), cocaine CPP followed by abstinence potentiated the effect of dynorphin. Last, these two neuropeptides also differ in their regulation of GABA release from D1- and D2MSN terminals in the VP after withdrawal from cocaine. In saline mice, both dynorphin and enkephalin depress GABA signaling from both D1 and D2-MSNs. However, after cocaine CPP and abstinence the effect of dynorphin on D1- and D2-MSN terminals persists (Fig. 6), whereas the enkephalinergic effect on D2-MSN terminals is abolished after withdrawal (Heinsbroek et al., 2017). Collectively, these findings draw an interesting picture, in which exposure to cocaine followed by a period of withdrawal preserves and even potentiates (for D1-MSNs) the postsynaptic effect of dynorphin on D1- and D2-MSN synapses on $\mathrm{VP}_{\mathrm{GABA}}$ neurons, whereas it abolishes the presynaptic enkephalin-induced regu-

\section{$\leftarrow$}

neurons of saline animals (time course, two-way repeatedmeasures ANOVA: $F_{(1,113)}=49.5, p<0.0001$; averages: ${ }^{*} p=0.007$, one-samplet test comparing to $0 \%$ change, $\# p<$ 0.0001 comparing to cocaine group). Abstinence from cocaine abolished this effect. $\boldsymbol{E}$, Representative traces of evoked IPSCS in $\mathrm{VP}_{\mathrm{VGluT} 2}$ neurons corresponding to the data in $\boldsymbol{C}$ and $\boldsymbol{D}$. $\boldsymbol{F}-\boldsymbol{K}$, Dynorphin did not affect the amplitude $(\boldsymbol{F}-\boldsymbol{H})$ or IEI $(\boldsymbol{I}-\boldsymbol{K})$ of sIPSCs recorded in $\mathrm{VP}_{\mathrm{vGluT} 2}$ neurons in either saline or cocaine mice (time courses, tested with two-way repeated-measures ANOVA; cumulative curves, with Kolmogorov-Smirnov test, lines are fitted sigmoidal curves running from 0 to 100). Data from 7 to 12 cells and $3-4$ mice per group for all conditions. 
lation of GABA release specifically from D2-MSN but not D1MSN terminals. This may imply an increase in the influence of the dynorphinergic system in the VP after cocaine CPP and abstinence.

Dynorphin regulation of GABA neurotransmission in the VP Our results show a clear link between the dynorphin activation of KORs in the VP and GABA neurotransmission. However, the underlying mechanisms are yet to be explored. Our data suggest that the modulation of IPSCs in the VP by dynorphin is mediated through a postsynaptic mechanism (Figs. 2,3). This is in line with previous anatomical studies showing robust expression of KORs in VP neurons (Allen Institute for Brain Science, 2004), but to the best of our knowledge this is the first report of a dynorphininduced postsynaptic modulation of synaptic neurotransmission. An abundance of studies show that KORs modulate the release of various neurotransmitters in different brain regions (Ogura and Kita, 2000; Mu et al., 2011; Li et al., 2012; Gilpin et al., 2014; Brooks and O'Donnell, 2017; Tejeda et al., 2017; Kash and Li, 2018; Matzeu et al., 2018; Tejeda and Bonci, 2019). In all of these studies the mechanism is presynaptic, even when the KORs show a postsynaptic effect on the passive electrical properties of the recorded neurons (Ogura and Kita, 2000).

Our data show that dynorphin has opposing effects on GABA neurotransmission in $\mathrm{VP}_{\mathrm{GABA}}$ and $\mathrm{VP}_{\mathrm{vGluT2}}$ neurons. Although the suppressive effect of dynorphin on GABA input to $\mathrm{VP}_{\mathrm{GABA}}$ neurons joins many other studies showing that dynorphin inhibits neurotransmitter release, the potentiating effect of dynorphin on GABA neurotransmission in $\mathrm{VP}_{\mathrm{vGluT} 2}$ neurons is surprising. How could dynorphin exert opposing effects on GABA neurotransmission in these two neuronal populations? The answer may lie in the diversity of intracellular cascades that can be activated by KORs (Bruchas and Chavkin, 2010), most of which can influence $\mathrm{GABA}_{\mathrm{A}}$ receptor function. Interestingly, although some cascades are expected to diminish synaptic $\mathrm{GABA}_{\mathrm{A}}$ receptor number or function, others may enhance the efficacy of synaptic inhibition. For example, activation of KORs reduces $\mathrm{Ca}^{2+}$ influx into the cells (Rusin et al., 1997). $\mathrm{Ca}^{2+}$ is known to promote the activation of gephyrin, which recruits $\mathrm{GABA}_{\mathrm{A}}$ receptors to the synapse (Zacchi et al., 2014; Choii and Ko, 2015). Therefore, such cascade is expected to weaken the inhibitory synapse. In contrast, binding to KORs activates the mitogen-activated protein kinases/ extracellular signal-regulated kinases (MAPK/ERK) pathway (Bruchas and Chavkin, 2010). ERK, in turn, may inhibit $\mathrm{GABA}_{\mathrm{A}}$ receptor internalization (Jurd and Moss, 2010) and promote the recruitment of $\mathrm{GABA}_{\mathrm{A}}$ receptors to the synapse through clustering gephyrin (Battaglia et al., 2018). Therefore, this cascade would potentiate the GABAergic synapse. This diversity in the possible outcomes of KOR activation may underlie the different effects of dynorphin in $\mathrm{VP}_{\mathrm{GABA}}$ and $\mathrm{VP}_{\mathrm{vGluT2}}$ neurons. At this point, the exact mechanisms governing either postsynaptic action of dynorphin in the VP is not known and clarifying the mechanisms in each cell type requires further investigation.

It should be noted that in this study we did not mimic the physiological release of dynorphin. Indeed, dynorphin release in the VP may be dynamic, depend on the rate of cellular activity and differ between different conditions or cell types. Thus, although we propose here a cellular mechanism of action for dynorphin in the VP, its in vivo influence on behavior is likely more complex and cannot be inferred directly from our data.
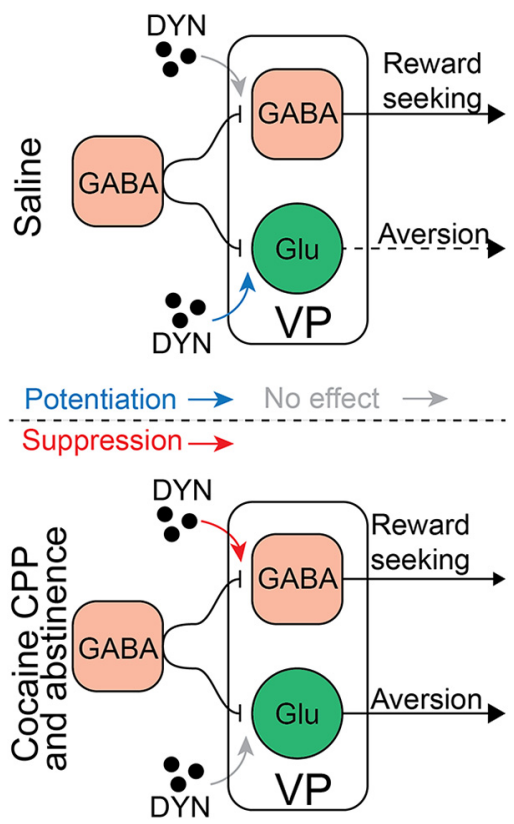

Figure 8. A possible mechanism of action for dynorphin in the VP before and after withdrawal from cocaine. Top, Effect of dynorphin on GABA neurotransmission on $\mathrm{VP}_{G A B A}$ and $\mathrm{VP}_{\mathrm{v}}$ GluT2 neurons in cocaine-naive animals. Dynorphin does not affect inhibitory input to $\mathrm{VP}_{\mathrm{GABA}}$ cells but potentiates the inhibitory input onto $\mathrm{VP}_{\mathrm{vGlu} 2}$ neurons. Thus, release of dynorphin in the VP of drug-naive mice is expected to decrease the activity of $\mathrm{VP}_{\mathrm{vGluT} 2}$ neurons. Because activation of $V P_{v G l u T 2}$ neurons was shown before to drive aversive behavior, the action of dynorphin may translate to a decrease in aversion. In contrast, after cocaine CPP and abstinence (bottom) dynorphin suppresses the inhibitory input on $\mathrm{VP}_{\mathrm{GABA}}$ neurons but ceases to modulate the inhibitory drive on $V_{P_{v G l u T}}$ neurons. Thus, spilling dynorphin in the VP after cocaine CPP and abstinence is expected to disinhibit $\mathrm{VP}_{\mathrm{GABA}}$ neurons while not affecting $\mathrm{VP}_{\mathrm{vGluT} 2}$ neurons. In other words, it may shift the $\mathrm{VP}_{\mathrm{GABA}} / \mathrm{VP}_{\mathrm{vGlu}}$ i 2 balance in favor of the $\mathrm{VP}_{\mathrm{GABA}}$ neurons. Because activation of $\mathrm{VP}_{\mathrm{GABA}}$ neurons is known to promote reward-seeking behavior, the action of dynorphin in the VP after cocaine CPP and abstinence may favor reward-seeking behavior.

Potential influences of VP dynorphin on reward and aversion A possible interpretation of our data is that dynorphin release in the VP may influence the production of drug-seeking and aversive behavior through its differential effects on $\mathrm{VP}_{\mathrm{GABA}}$ and $\mathrm{VP}_{\mathrm{v}}$ GluT2 neurons (Figs. 2, 7, summarized in 8). Moreover, this influence may be altered by exposure to cocaine. This interpretation relies on recent studies showing that $\mathrm{VP}_{\mathrm{GABA}}$ neurons promote reward-seeking behaviors, whereas $\mathrm{VP}_{\mathrm{vGluT}}$ neurons encode aversive states (Faget et al., 2018; Tooley et al., 2018; Wulff et al., 2019). In saline-treated mice, dynorphin did not affect the inhibitory input to $\mathrm{VP}_{\mathrm{GABA}}$ neurons (Fig. 2) but potentiated the inhibitory input to $\mathrm{VP}_{\mathrm{vGluT2}}$ neurons (Fig. 7). This may imply that in control mice the release of dynorphin promotes inhibition of $\mathrm{VP}_{\mathrm{vGluT2}}$ neurons, which would be expected to result in decreased aversive behavior (Fig. 8). After cocaine CPP and abstinence, on the other hand, dynorphin acts in a completely different manner; its modulation of $\mathrm{VP}_{\mathrm{vGluT2}}$ neurons is abolished but it now depresses the inhibitory input on $\mathrm{VP}_{\mathrm{GABA}}$ neurons. In other words, dynorphin ceases to modulate the presumed "aversive pathway" but now promotes the activation of $\mathrm{VP}_{\mathrm{GABA}}$ neurons, which drive reward seeking (Fig. 8). Note that both in control mice and after cocaine CPP and abstinence, dynorphin seems to shift the ratio between $\mathrm{VP}_{\mathrm{GABA}}$ and $\mathrm{VP}_{\mathrm{vGluT2}}$ activity in favor of the $\mathrm{VP}_{\mathrm{GABA}}$ neurons. In saline mice, this is a result of increasing the inhibition onto $\mathrm{VP}_{\mathrm{vGluT} 2}$ neurons. In mice that underwent cocaine CPP and abstinence this effect is attributed to the disinhibition of $\mathrm{VP}_{\mathrm{GABA}}$ neurons. Taking into account 
the opposing behavioral influences of $\mathrm{VP}_{\mathrm{GABA}}$ and $\mathrm{VP}_{\mathrm{vGluT2}}$ neurons mentioned above, these data may imply that release of dynorphin in the VP may have an overall rewarding effect. Because the majority of the dynorphin in the VP presumably originates in NAc D1-MSNs, dynorphin release may allow the D1-MSN input to the VP to shift the $\mathrm{VP}_{\mathrm{GABA}} / \mathrm{VP}_{\mathrm{vGluT}}$ balance in favor of $\mathrm{VP}_{\mathrm{GABA}}$, and thus possibly contribute to the promotion of drug-seeking behavior.

\section{References}

Allen Institute for Brain Science (2004) Allen mouse brain atlas. Retrieved November 27, 2018. Available at http://mouse.brain-map.org/gene/show/18156.

Arvidsson U, Riedl M, Chakrabarti S, Vulchanova L, Lee JH, Nakano AH, Lin X, Loh HH, Law PY, Wessendorf MW (1995) The kappa-opioid receptor is primarily postsynaptic: combined immunohistochemical localization of the receptor and endogenous opioids. Proc Natl Acad Sci U S A 92:5062-5066.

Barrientos C, Knowland D, Wu MMJ, Lilascharoen V, Huang KW, Malenka RC, Lim BK (2018) Cocaine-induced structural plasticity in input regions to distinct cell types in nucleus accumbens. Biol Psychiatry 84:893-904.

Battaglia S, Renner M, Russeau M, Côme E, Tyagarajan SK, Lévi S (2018) Activity-dependent inhibitory synapse scaling is determined by gephyrin phosphorylation and subsequent regulation of GABAA receptor diffusion. eNeuro 5:ENEURO.0203-17.2017.

Bengtson CP, Osborne PB (2000) Electrophysiological properties of cholinergic and noncholinergic neurons in the ventral pallidal region of the nucleus basalis in rat brain slices. J Neurophysiol 83:2649-2660.

Bock R, Shin JH, Kaplan AR, Dobi A, Markey E, Kramer PF, Gremel CM, Christensen CH, Adrover MF, Alvarez VA (2013) Strengthening the accumbal indirect pathway promotes resilience to compulsive cocaine use. Nat Neurosci 16:632-638.

Brooks JM, O’Donnell P (2017) $\kappa$-Opioid receptors mediate heterosynaptic suppression of hippocampal inputs in the rat ventral striatum. J Neurosci 37:7140-7148.

Bruchas MR, Chavkin C (2010) Kinase cascades and ligand-directed signaling at the kappa opioid receptor. Psychopharmacology 210:137-147.

Chavkin C, Koob GF (2016) Dynorphin, dysphoria, and dependence: the stress of addiction. Neuropsychopharmacology 41:373-374.

Chavkin C, James IF, Goldstein A (1982) Dynorphin is a specific endogenous ligand of the kappa opioid receptor. Science 215:413-415.

Choii G, Ko J (2015) Gephyrin: a central GABAergic synapse organizer. Exp Mol Med 47:e158.

Chou TC, Lee CE, Lu J, Elmquist JK, Hara J, Willie JT, Beuckmann CT, Chemelli RM, Sakurai T, Yanagisawa M, Saper CB, Scammell TE (2001) Orexin (hypocretin) neurons contain dynorphin. J Neurosci 21:RC168.

Conrad KL, Tseng KY, Uejima JL, Reimers JM, Heng LJ, Shaham Y, Marinelli M, Wolf ME (2008) Formation of accumbens GluR2-lacking AMPA receptors mediates incubation of cocaine craving. Nature 454:118-121.

Creed M, Ntamati NR, Chandra R, Lobo MK, Lüscher C (2016) Convergence of reinforcing and anhedonic cocaine effects in the ventral pallidum. Neuron 92:214-226.

Dong Y, Taylor JR, Wolf ME, Shaham Y (2017) Circuit and synaptic plasticity mechanisms of drug relapse. J Neurosci 37:10867-10876.

Faget L, Zell V, Souter E, McPherson A, Ressler R, Gutierrez-Reed N, Yoo JH, Dulcis D, Hnasko TS (2018) Opponent control of behavioral reinforcement by inhibitory and excitatory projections from the ventral pallidum. Nat Commun 9:849.

Frankel PS, Alburges ME, Bush L, Hanson GR, Kish SJ (2008) Striatal and ventral pallidum dynorphin concentrations are markedly increased in human chronic cocaine users. Neuropharmacology 55:41-46.

Gallo EF, Meszaros J, Sherman JD, Chohan MO, Teboul E, Choi CS, Moore H, Javitch JA, Kellendonk C (2018) Accumbens dopamine D2 receptors increase motivation by decreasing inhibitory transmission to the ventral pallidum. Nat Commun 9:1086.

Geisler S, Derst C, Veh RW, Zahm DS (2007) Glutamatergic afferents of the ventral tegmental area in the rat. J Neurosci 27:5730-5743.

Gerfen CR, Surmeier DJ (2011) Modulation of striatal projection systems by dopamine. Annu Rev Neurosci 34:441-466.

Gilpin NW, Roberto M, Koob GF, Schweitzer P (2014) Kappa opioid recep- tor activation decreases inhibitory transmission and antagonizes alcohol effects in rat central amygdala. Neuropharmacology 77:294-302.

Gipson CD, Kupchik YM, Shen H, Reissner KJ, Thomas CA, Kalivas PW (2013) Relapse induced by cues predicting cocaine depends on rapid, transient synaptic potentiation. Neuron 77:867-872.

Heimer L, Zahm DS, Churchill L, Kalivas PW, Wohltmann C (1991) Specificity in the projection patterns of accumbal core and shell in the rat. Neuroscience 41:89-125.

Heinsbroek JA, Neuhofer DN, Griffin WC 3rd, Siegel GS, Bobadilla AC, Kupchik YM, Kalivas PW (2017) Loss of plasticity in the D2-accumbens pallidal pathway promotes cocaine seeking. J Neurosci 37:757-767.

Ho CY, Berridge KC (2013) An orexin hotspot in ventral pallidum amplifies hedonic "liking" for sweetness. Neuropsychopharmacology 38:1655-1664.

Hubner CB, Koob GF (1990) The ventral pallidum plays a role in mediating cocaine and heroin self-administration in the rat. Brain Res 508:20-29.

Hur EE, Zaborszky L (2005) Vglut2 afferents to the medial prefrontal and primary somatosensory cortices: a combined retrograde tracing in situ hybridization study [corrected]. J Comp Neurol 483:351-373.

Hurd YL, Brown EE, Finlay JM, Fibiger HC, Gerfen CR (1992) Cocaine self-administration differentially alters mRNA expression of striatal peptides. Brain Res Mol Brain Res 13:165-170.

Jurd R, Moss SJ (2010) Impaired GABA(A) receptor endocytosis and its correlation to spatial memory deficits. Commun Integr Biol 3:176-178.

Kalivas PW, Volkow ND (2005) The neural basis of addiction: a pathology of motivation and choice. Am J Psychiatry 162:1403-1413.

Kash T, Li C (2018) Kappa opioid receptor modulation on GABAergic inputs onto ventral periaqueductal gray dopamine neurons. bioRxiv 389536.

Khachaturian H, Watson SJ, Lewis ME, Coy D, Goldstein A, Akil H (1982) Dynorphin immunocytochemistry in the rat central nervous system. Peptides 3:941-954.

Kupchik YM, Kalivas PW (2013) The rostral subcommissural ventral pallidum is a mix of ventral pallidal neurons and neurons from adjacent areas: an electrophysiological study. Brain Struct Funct 218:1487-1500.

Kupchik YM, Scofield MD, Rice KC, Cheng K, Roques BP, Kalivas PW (2014) Cocaine dysregulates opioid gating of GABA neurotransmission in the ventral pallidum. J Neurosci 34:1057-1066.

Kupchik YM, Brown RM, Heinsbroek JA, Lobo MK, Schwartz DJ, Kalivas PW (2015) Coding the direct/indirect pathways by D1 and D2 receptors is not valid for accumbens projections. Nat Neurosci 18:1230-1232.

Land BB, Bruchas MR, Lemos JC, Xu M, Melief EJ, Chavkin C (2008) The dysphoric component of stress is encoded by activation of the dynorphin -opioid system. J Neurosci 28:407-414.

Lein ES, Hawrylycz MJ, Ao N, Ayres M, Bensinger A, Bernard A, Boe AF, Boguski MS, Brockway KS, Byrnes EJ, Chen L, Chen L, Chen TM, Chin MC, Chong J, Crook BE, Czaplinska A, Dang CN, Datta S, Dee NR, et al. (2007) Genome-wide atlas of gene expression in the adult mouse brain. Nature 445:168-176.

Li C, Pleil KE, Stamatakis AM, Busan S, Vong L, Lowell BB, Stuber GD, Kash TL (2012) Presynaptic inhibition of gamma-aminobutyric acid release in the bed nucleus of the stria terminalis by kappa opioid receptor signaling. Biol Psychiatry 71:725-732.

Lu XY, Ghasemzadeh MB, Kalivas PW (1998) Expression of D1 receptor, $D 2$ receptor, substance $P$ and enkephalin messenger RNAs in the neurons projecting from the nucleus accumbens. Neuroscience 82:767-780.

Lüscher C (2016) The emergence of a circuit model for addiction. Annu Rev Neurosci 39:257-276.

Mansour A, Fox CA, Burke S, Meng F, Thompson RC, Akil H, Watson SJ (1994) Mu, delta, and kappa opioid receptor mRNA expression in the rat CNS: an in situ hybridization study. J Comp Neurol 350:412-438.

Matsui A, Alvarez VA (2018) Cocaine inhibition of synaptic transmission in the ventral pallidum is pathway-specific and mediated by serotonin. Cell Rep 23:3852-3863.

Matzeu A, Kallupi M, George O, Schweitzer P, Martin-Fardon R (2018) Dynorphin counteracts orexin in the paraventricular nucleus of the thalamus: cellular and behavioral evidence. Neuropsychopharmacology 43: 1010-1020.

Mu P, Neumann PA, Panksepp J, Schlüter OM, Dong Y (2011) Exposure to cocaine alters dynorphin-mediated regulation of excitatory synaptic transmission in nucleus accumbens neurons. Biol Psychiatry 69:228-235.

Ogura M, Kita H (2000) Dynorphin exerts both postsynaptic and presynaptic effects in the globus pallidus of the rat. J Neurophysiol 83:3366-3376. 
Olive MF, Anton B, Micevych P, Evans CJ, Maidment NT (1997) Presynaptic versus postsynaptic localization of $\mu$ - and $\delta$-opioid receptors in dorsal and ventral striatopallidal pathways. J Neurosci 17:7471-7479.

Pardo-Garcia TR, Garcia-Keller C, Penaloza T, Richie CT, Pickel J, Hope BT, Harvey BK, Kalivas PW, Heinsbroek JA (2019) Ventral pallidum is the primary target for accumbens D1 projections driving cocaine seeking. J Neurosci 39:2041-2051.

Prasad AA, McNally GP (2016) Ventral pallidum output pathways in context-induced reinstatement of alcohol seeking. J Neurosci 36:11716-11726.

Richard JM, Ambroggi F, Janak PH, Fields HL (2016) Ventral pallidum neurons encode incentive value and promote cue-elicited instrumental actions. Neuron 90:1165-1173.

Richard JM, Stout N, Acs D, Janak PH (2018) Ventral pallidal encoding of reward-seeking behavior depends on the underlying associative structure. eLife 7:e33107.

Root DH, Melendez RI, Zaborszky L, Napier TC (2015) The ventral pallidum: subregion-specific functional anatomy and roles in motivated behaviors. Prog Neurobiol 130:29-70.

Rusin KI, Giovannucci DR, Stuenkel EL, Moises HC (1997) $\kappa$-Opioid receptor activation modulates $\mathrm{Ca}^{2+}$ currents and secretion in isolated neuroendocrine nerve terminals. J Neurosci 17:6565-6574.

Scofield MD, Heinsbroek JA, Gipson CD, Kupchik YM, Spencer S, Smith AC, Roberts-Wolfe D, Kalivas PW (2016) The nucleus accumbens: mechanisms of addiction across drug classes reflect the importance of glutamate homeostasis. Pharmacol Rev 68:816-871.

Shippenberg TS, Zapata A, Chefer VI (2007) Dynorphin and the pathophysiology of drug addiction. Pharmacol Ther 116:306-321.

Smith KS, Berridge KC (2005) The ventral pallidum and hedonic reward: neurochemical maps of sucrose "liking" and food intake. J Neurosci 25:8637-8649.

Soares-Cunha C, Coimbra B, David-Pereira A, Borges S, Pinto L, Costa P, Sousa N, Rodrigues AJ (2016) Activation of D2 dopamine receptorexpressing neurons in the nucleus accumbens increases motivation. Nat Commun 7:11829.

Stefanik MT, Kupchik YM, Brown RM, Kalivas PW (2013) Optogenetic evidence that pallidal projections, not nigral projections, from the nucleus accumbens core are necessary for reinstating cocaine seeking. J Neurosci $33: 13654-13662$.
Tachibana Y, Hikosaka O (2012) The primate ventral pallidum encodes expected reward value and regulates motor action. Neuron 76:826-837.

Tejeda HA, Bonci A (2019) Dynorphin/kappa-opioid receptor control of dopamine dynamics: implications for negative affective states and psychiatric disorders. Brain Res 1713:91-101.

Tejeda HA, Wu J, Kornspun AR, Pignatelli M, Kashtelyan V, Krashes MJ, Lowell BB, Carlezon WA Jr, Bonci A (2017) Pathway- and cell-specific kappa-opioid receptor modulation of excitation-inhibition balance differentially gates D1 and D2 accumbens neuron activity. Neuron 93:147-163.

Thomas TS, Baimel C, Borgland SL (2018) Opioid and hypocretin neuromodulation of ventral tegmental area neuronal subpopulations. $\mathrm{Br} \mathrm{J}$ Pharmacol 175:2825-2833.

Tindell AJ, Berridge KC, Zhang J, Peciña S, Aldridge JW (2005) Ventral pallidal neurons code incentive motivation: amplification by mesolimbic sensitization and amphetamine. Eur J Neurosci 22:2617-2634.

Tindell AJ, Smith KS, Peciña S, Berridge KC, Aldridge JW (2006) Ventral pallidum firing codes hedonic reward: when a bad taste turns good. J Neurophysiol 96:2399-2409.

Tooley J, Marconi L, Alipio JB, Matikainen-Ankney B, Georgiou P, Kravitz AV, Creed MC (2018) Glutamatergic ventral pallidal neurons modulate activity of the habenula-tegmental circuitry and constrain reward seeking. Biol Psychiatry 83:1012-1023.

Turner BD, Rook JM, Lindsley CW, Conn PJ, Grueter BA (2018) mGlu1 and mGlu5 modulate distinct excitatory inputs to the nucleus accumbens shell. Neuropsychopharmacology 43:2075-2082.

Wulff AB, Tooley J, Marconi LJ, Creed MC (2019) Ventral pallidal modulation of aversion processing. Brain Res 1713:62-69.

Zacchi P, Antonelli R, Cherubini E (2014) Gephyrin phosphorylation in the functional organization and plasticity of GABAergic synapses. Front Cell Neurosci 8:103.

Zahm DS, Heimer L (1990) Two transpallidal pathways originating in the rat nucleus accumbens. J Comp Neurol 302:437-446.

Zahm DS, Zaborszky L, Alones VE, Heimer L (1985) Evidence for the coexistence of glutamate decarboxylase and met-enkephalin immunoreactivities in axon terminals of rat ventral pallidum. Brain Res 325:317-321.

Zhang S, Tong Y, Tian M, Dehaven RN, Cortesburgos L, Mansson E, Simonin F, Kieffer B, Yu L (1998) Dynorphin A as a potential endogenous ligand for four members of the opioid receptor gene family. J Pharmacol Exp Ther 286:136-141. 